\section{Cysticercosis-related mortality in the State of São Paulo, Brazil, 1985-2004: a study using multiple causes of death}

\author{
Tendência da mortalidade relacionada à \\ cisticercose no Estado de São Paulo, Brasil, 1985 a \\ 2004: estudo usando causas múltiplas de morte
}

\section{${ }^{1}$ Faculdade de Saúde Pública, Universidade de São Paulo, São Paulo, Brasil. \\ Correspondence A. H. Santo Faculdade de Saúde Pública Universidade de São Paulo. Rua Pará 21, apto. 62, São Paulo, SP 01243-020, Brasil. auhsanto@usp.br}

\begin{abstract}
Cysticercosis-related mortality has not been studied in Brazil. Deaths recorded in the State of São Paulo from 1985 to 2004 in which cysticercosis was mentioned on any line or in any part of the death certificate were studied. Causes of death were processed using the Multiple Cause Tabulator. Over this 20-year period, cysticercosis was identified in 1,570 deaths: as the underlying cause in 1,131 and as an associated cause of death in 439. Standardized mortality rates with cysticercosis as the underlying cause showed a downward trend and were higher among men and older individuals. Intracranial hypertension, cerebral edema, hydrocephalus, inflammatory diseases of the central nervous system, and cerebrovascular diseases were the main associated causes in deaths due to cysticercosis. AIDS was the principal underlying cause of death in which cysticercosis was an associated cause. The counties (municipalities) with the most cysticercosis-related deaths were São Paulo, Campinas, Ribeirão Preto, and Santo André. Wide variation was observed between counties regarding the value ascribed to cysticercosis as the underlying cause of death. This leads to underestimation of the disease's importance in planning health interventions.
\end{abstract}

Cysticercosis; Multiple Cause of Death; Mortality Rate
Augusto Hasiak Santo 1

\section{Introduction}

Cysticercosis of the central nervous system (CNS), or neurocysticercosis, is an infection caused by the larval stage (cysticerci) of the pork tapeworm Taenia solium. The life cycle of this tapeworm includes humans as definitive hosts and swine as intermediate hosts. Pigs are infected when they ingest human feces containing microscopic $T$. solium eggs, which develop into cysticerci in the muscle and brain. After eating undercooked pork containing viable cysticerci, humans develop an intestinal tapeworm infestation, thus completing the natural evolutionary cycle. However, humans can also become intermediate hosts by directly ingesting T. solium eggs from feces of human carriers of the parasite. Humans are thus anomalous intermediate hosts in human cysticercosis. These eggs then develop into cysticerci, which migrate into muscle and the CNS, where the cysticerci can cause seizures and various other neurological symptoms. Both these forms of human cysticercosis are therefore human-to-human infections acquired by fecal-oral contamination in areas with poor hygiene and sanitation. Cysticercosis of the CNS is the most important neurological disease of parasitic origin in humans and is currently widespread around the world and one of the main health problems in the developing countries of Africa, Asia, and Latin America. The disease causes serious morbidity, and in areas where T. solium is endemic it is known to be a 
leading cause of epilepsy. In Latin America, approximately $30 \%$ of all seizures are associated with cysticercosis. Almost 50,000 deaths attributable to neurocysticercosis occur every year. The severity of cysticercosis can also be illustrated by its case-fatality rate, varying from $16.4 \%$ to $25.9 \%$ $1,2,3,4,5,6$.

Our search of the Brazilian literature failed to yield any references to cysticercosis-related population mortality. One study that attempted to compile the available research from the Brazilian literature on human neurocysticercosis presented data on hospital deaths and autopsy observations 7 . However, although such studies with limited criteria provide valuable information, they can underestimate the impact of cysticercosis as a cause of death ${ }^{4,8}$. Neurocysticercosis as cause of death may be an incidental finding, an underlying cause, or an associated cause of death 9 . Likewise, underestimation of the extent of cysticercosis-related mortality occurs in statistics that consider only the underlying cause 10. Among the 124 cysticercosis-related deaths in California from 1989 to 2000, the disease was specified as the underlying cause in only $92(74.2 \%)$ and as an associated cause in the remaining 32 (23.8\%), thus characterizing underestimation if considered only as the underlying cause 8 .

Brazilian national mortality data are obtained from death certificates completed by physicians or prepared through reports by witnesses, and are recorded in notary public offices 11 . The demographic and medical data on death certificates are coded and processed by vital statistics or epidemiological surveillance services in the States and sent to the Ministry of Health to be consolidated as nationwide data 12 . Among such data, causes of death are particularly important. The underlying cause is defined as "(a) disease or injury which initiated the chain of pathological events leading directly to death or (b) the circumstances of the accident or violence which produced the fatal injury" 13 (p. 32). With the aim of preventing death, primary mortality data are traditionally presented according to the underlying cause. Despite the great value of the underlying cause, in recent decades there has been an increasing demand for all causes of death recorded on death certificates to be presented, and not only the underlying cause. Such statistics are called multiple-cause-of-death data and provide information on the entire range of processes that culminate in death, thereby offering new information and prospects for prevention 10 .

The current study focused on the cysticercosis-related mortality trend in the State of São Paulo, Brazil, from 1985 to 2004, considering all deaths in which cysticercosis was mentioned on any line or in any part of the death certificate, and not only when identified as the underlying cause of death.

\section{Material and methods}

Mortality data were obtained from the annual database for multiple causes of death of the Fundação Sistema Estadual de Análise de Dados [SEADE Foundation; Data Analysis System Foundation], which is responsible for compiling vital statistics in the State of São Paulo. The population data came from Departamento de Informática do SUS [DATASUS; the Information Technology Department of the Brazilian Unified National Health System, Brazilian Ministry of Health]. All deaths in which cysticercosis was mentioned on any line or in any part of the death certificate were considered, irrespective of whether cysticercosis was specified as the underlying cause or an associated (i.e., not underlying) cause of death. The study required modifying the structure of the records included in the database that reproduced the respective items from the fields on the death certificate. From 1985 to 2004, various fields underwent changes in the designation, sizes, and codes used for the variables, and there were also two revisions in the International Classification of Diseases (ICD) during this period. The characteristics of the fields were standardized, and new fields were created to consolidate the annual files for the 20-year period and facilitate the processing.

Causes of death were automatically processed using the Automated Classification of Medical Entities (ACME) for 1985 to 199510 and the São Paulo State Death Certificates software 14, with adaptation for batch processing using the Selection of Underlying Cause (SCB) system 15 for 1996 to 2004. A review was made of the records in which cysticercosis was mentioned in the death certificate but not specified as the underlying cause. Automatic processing used algorithms and decision tables that incorporated the mortality rules of the World Health Organization (WHO) and the etiological relationships between causes of death. This review aimed to ensure appropriate identification of cysticercosis as the underlying cause of death $10,14,15,16,17$.

In order to reconstitute the disease process leading to death, all causes of death were considered in this study, even those classified as ill-defined or characterized by WHO as "modes of death" 13. Cysticercosis corresponded to the clinical forms included in subcategory 123.1 and category B69 (cysticercosis), respectively, of the 9 th and $10^{\text {th }}$ ICD revisions (ICD-9 and ICD-10) 
18,19. Equivalence tables were prepared to compare trends in associated causes of death related to cysticercosis, between these two revisions. The expressions "deaths from" or "deaths due to" a given disease referred to the underlying cause of death, and the expressions "deaths with mention of" or "cysticercosis-related mortality" corresponded to the presence of this disease as either the underlying cause or an associated (not underlying) cause on the death certificate. Causes of death used in the study were those actually mentioned on the death certificate, which are known internationally as "entity axis codes", as defined and presented by means of ICD structures and rubrics 10 .

Distribution of deaths was studied according to sex, age, seasonality, historical trend, underlying and associated causes of death, number of causes listed per death certificate, county of residence, and location where death occurred. Demographic and medical variables were processed using the programs dBASE III Plus, version 1.1 (Ashton Tate Corporation, U.S.A.), Epi Info, version 6.04d (Centers for Disease Control and Prevention, Atlanta, U.S.A.), and Excel 1997 (Microsoft Corp., U.S.A.). Multiple Cause Tabulator (MCT) with versions for ICD-9 and ICD-10 (MCT-9, version 4.0, and MCT-10, version 2.2) was used to present the associated causes and the mean number of causes per death certificate 20 . To present the associated causes in the deaths in which cysticercosis was identified as the underlying cause, special lists were prepared that showed both the causes involved in the natural history of cysticercosis and those mentioned most frequently. Duplication or multiplication of causes of death was eliminated from the presentation by means of abbreviated lists. Considering that the number of causes depends on the amplitude of the class, only one cause was computed if two (or more) causes mentioned in the death certificate were included in the same class 10,20. The program Mortality Record Separator (SRM_DBF) version 3.1 (DATASUS, Brazil) was used to retrieve records in which there was interest in certain associated causes of death.

Mortality rates (per 1,000,000 inhabitants) were calculated for deaths in which cysticercosis was identified as the underlying cause or an associate cause, and also for the total number of times it was mentioned. The Epidemiological Analysis Program for Tabulated Data (Epidat), version 3.0 (http://dxsp.sergas.es, Regional Government of Galicia, Spain) was used to standardize the mortality rates for 1985 to 2004 by sex and age according to Brazil's population in 2000. Standardized rates were presented with their respective confidence intervals. Deaths with unknown sex or age were eliminated from the calculations of age at death and of the specific rates according to age and sex. The mean number of causes stated per death certificate was presented with the respective standard deviation.

\section{Results}

From 1985 to 2004 there were 1,570 cysticercosis-related deaths in the State of São Paulo, of which 1,131 (72.04\%) had cysticercosis specified as the underlying cause and $439(27.96 \%)$ as an associated cause of death. The mean number of deaths was 79 per year, ranging from 54 in 2001 to 103 in 1993. These corresponded to standardized mortality rates (for the total number of times cysticercosis was mentioned) of 1.34 and 3.37 deaths $/ 1,000,000$ inhabitants, respectively. Table 1 shows the demographic characteristics of these deaths according to four sub-periods. There were proportionally more men (56.1\%) among all the deaths with cysticercosis mentioned. Most of the deaths occurred between 20 and 69 years of age when cysticercosis was the underlying cause $(85.3 \%)$ and between 30 and 79 when it was an associated cause $(82.7 \%)$. Median age at death was 43.5 years (range: $4-97$ ) for cysticercosis as underlying cause and 53.5 years (range: 1-93) as associated cause. Median age at death increased from the first to the last sub-periods, from 41.5 to 47.5 years, when cysticercosis was the underlying cause and from 46.5 to 60.5 years when it was an associated cause. Median age at death increased from 43.5 to 45.5 years for underlying cause in men and from 37.5 to 51.0 in women, and from 46.5 to 51.5 for associated cause in men and from 49.5 to 65.5 in women. Cysticercosis-related deaths did not show any noticeable variation according to the month of the year, and there was thus no evidence of seasonality.

\section{Mortality rates}

Age-standardized mortality rates for cysticercosis as the underlying cause showed a marked decline over the 20-year period, especially among men, and with rates that were always higher than for cysticercosis as associated cause of death (Figure 1). The highest mortality rate with cysticercosis as the underlying cause was 2.51 in 1987, and the lowest was 0.88 per 1,000,000 inhabitants in 2003. These values ranged from 3.05 in 1990 to 1.00 in 2003 for men and from 2.41 in 1986 to 0.65 in 2001 for women. With cysticercosis as associated cause, the rates did not vary noticeably, from a high of 1.16 in 1995 to a low of 0.32 deaths per $1,000,000$ inhabitants in 2001. The gender-spe- 


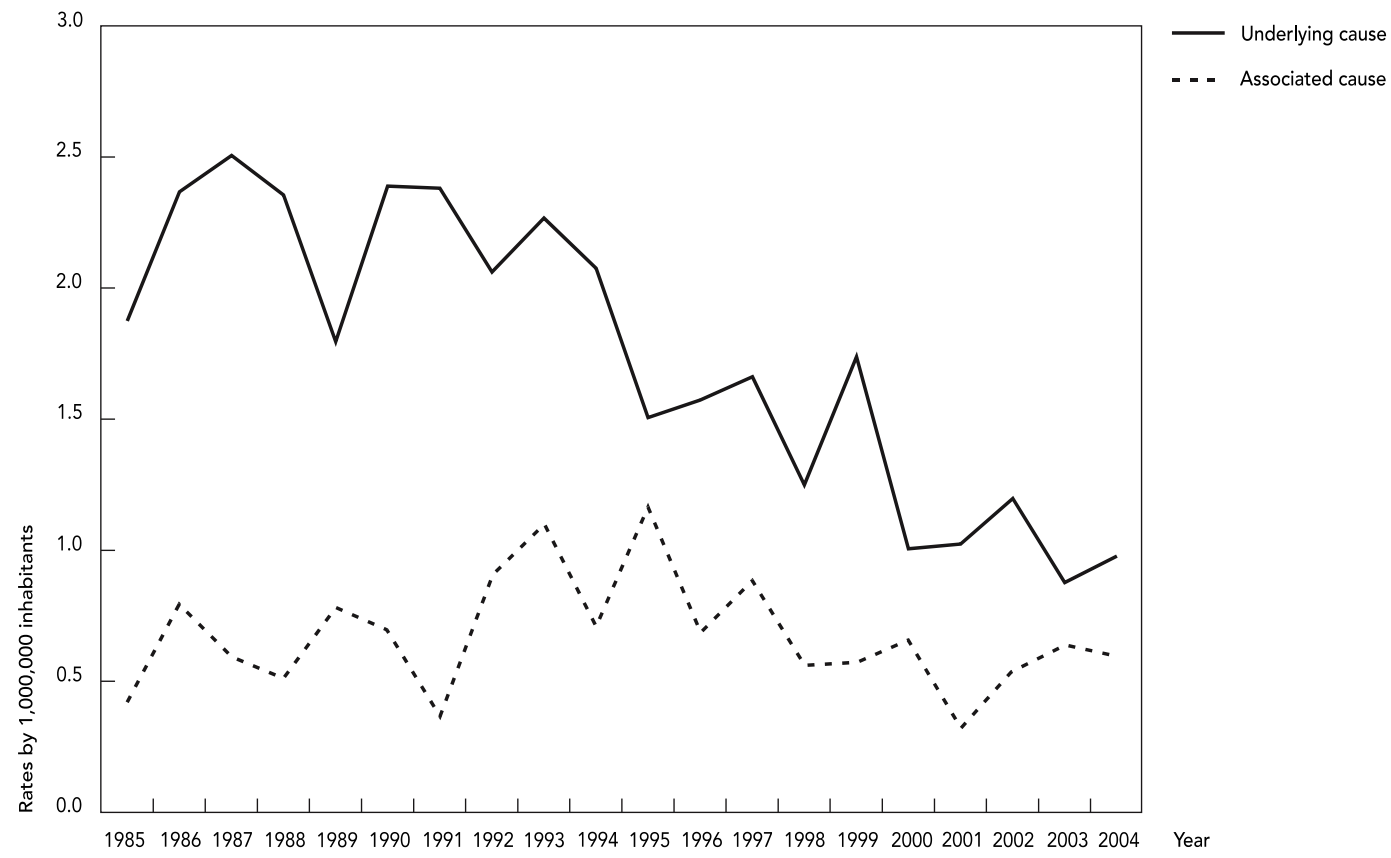

cific rates ranged from 1.56 in 1995 to 0.30 in 2001 for men and from 0.86 in 1992 to 0.24 in 1991 in women. Table 1 summarizes the trends for standardized cysticercosis-related mortality rates, for cysticercosis as the underlying cause and as associated cause, according to four sub-periods between 1985 and 2004 .

When all the death certificates in which cysticercosis was mentioned were considered, there was an increase in the mortality rate. Moreover, there were large variations in this increase between the standardized cysticercosis-related mortality rates according to the total number of times mentioned and the traditional rates defined according to the underlying cause of death. These increases, calculated as percentages over the rates based on underlying cause, ranged from $15.29 \%$ in 1991 to $77.3 \%$ in 1995. For the four sub-periods, the increases were $28.7 \%, 41.44 \%, 46.53 \%$, and $51.46 \%$, respectively, with a clear upward trend. Considering all the times cysticercosis was mentioned, there was a $39.81 \%$ increase in the 20 -year period. Thus, there was a steady decrease in the proportion of cases in which cysticercosis was identified as the underlying cause of death, ac- companied by an increase in the proportion of cases in which cysticercosis was listed as an associated cause.

\section{Associated causes of death with cysticercosis as the underlying cause}

Table 2 shows the associated causes of death listed on death certificates in which cysticercosis was identified as the underlying cause, in decreasing order for the first period (1985-1990). Causes representing direct complications of cysticercosis stand out, including intracranial hypertension, cerebral edema, hydrocephalus, inflammatory diseases of the CNS, and other diseases affecting the CNS, particularly cerebrovascular diseases. Hydrocephalus moved from the fourth most common associated cause in 1985-1990 to the most common in 2001-2004. Terminal conditions mentioned were pneumonia, respiratory failure, septicemia, shock, and coma. There was increasing mention of medical and surgical procedures as cofactors, from $1 \%$ in the first period to $6.6 \%$ in the last period. 
Cysticercosis-related mortality according to qualification of the cause of death, crude and standardized death rates, gender, age, median age at death, mean number of causes of death listed per death certificate, and time periods. São Paulo State, Brazil, 1985-2004.

\begin{tabular}{|c|c|c|c|c|c|c|c|c|c|c|}
\hline \multirow[t]{2}{*}{ Periods } & \multicolumn{5}{|c|}{ Underlying cause of death } & \multicolumn{5}{|c|}{ Associated (non-underlying) cause of death } \\
\hline & $1985-1990$ & 1991-1995 & $1996-2000$ & 2001-2004 & $1985-2004$ & $1985-1990$ & 1991-1995 & $1996-2000$ & 2001-2004 & $1985-2004$ \\
\hline \multicolumn{11}{|l|}{ Crude death rate (per } \\
\hline $1,000,000$ inhabitants) & 2.1298 & 1.9848 & 1.4836 & 1.0861 & 1.6850 & 0.5932 & 0.7902 & 0.6739 & 0.5528 & 0.6531 \\
\hline \multicolumn{11}{|l|}{ Standardized death } \\
\hline \multicolumn{11}{|l|}{ rate (per 1,000,000) and } \\
\hline \multicolumn{11}{|l|}{ respective confidence } \\
\hline \multicolumn{11}{|l|}{ intervals (Cl) } \\
\hline Rate & 2.2157 & 2.0519 & 1.4395 & 1.0180 & 1.6798 & 0.6359 & 0.8503 & 0.6698 & 0.5239 & 0.6688 \\
\hline Lower $\mathrm{Cl}$ & 1.9911 & 1.8274 & 1.2649 & 0.8634 & 1.5817 & 0.5134 & 0.7024 & 0.5491 & 0.4124 & 0.6059 \\
\hline Upper Cl & 2.4403 & 2.2764 & 1.6141 & 1.1725 & 1.7780 & 0.7584 & 0.9982 & 0.7905 & 0.6353 & 0.7317 \\
\hline \multirow{2}{*}{\multicolumn{11}{|c|}{$\begin{array}{l}\text { Sex: absolute number } \\
\text { (proportion) }\end{array}$}} \\
\hline & & & & & & & & & & \\
\hline Male & $216(57.3)$ & $191(59.0)$ & $137(52.1)$ & $95(56.9)$ & $639(56.5)$ & $56(52.8)$ & $79(61.2)$ & $73(61.3)$ & $34(40.0)$ & $242(55.1)$ \\
\hline Female & $161(42.7)$ & $133(41.0)$ & $126(47.9)$ & $72(43.1)$ & $492(43.5)$ & $50(47.2)$ & $50(38.8)$ & $46(38.7)$ & $51(60.0)$ & $197(44.9)$ \\
\hline \multirow[t]{2}{*}{ Total } & 377 & 324 & 263 & 167 & 1,131 & 106 & 129 & 119 & 85 & 439 \\
\hline & $(100.0)$ & (100.0) & (100.0) & (100.0) & (100.0) & $(100.0)$ & (100.0) & $(100.0)$ & $(100.0)$ & (100.0) \\
\hline \multicolumn{11}{|l|}{ Age in years: absolute } \\
\hline \multicolumn{11}{|l|}{ number (proportion) } \\
\hline $0-4$ & $0(0.0)$ & $1(0.3)$ & $0(0.0)$ & $0(0.0)$ & $1(0.1)$ & $0(0.0)$ & $1(0.8)$ & $1(0.8)$ & $0(0.0)$ & $2(0.5)$ \\
\hline $5-9$ & $0(0.0)$ & $2(0.6)$ & $2(0.8)$ & $0(0.0)$ & $4(0.4)$ & $1(1.0)$ & $0(0.0)$ & $0(0.0)$ & $0(0.0)$ & $1(0.2)$ \\
\hline $10-19$ & $23(6.1)$ & $13(4.0)$ & $8(3.1)$ & $5(3.0)$ & $49(4.3)$ & $2(1.9)$ & $2(1.6)$ & $2(1.7)$ & $1(1.2)$ & $7(1.6)$ \\
\hline $20-29$ & $58(15.4)$ & 38 (11.7) & $32(12.2)$ & $17(10.2)$ & $145(12.8)$ & $10(9.5)$ & $11(8.5)$ & $6(5.0)$ & $4(4.7)$ & $31(7.1)$ \\
\hline $30-39$ & $91(24.1)$ & $69(21.3)$ & 55 (21.0) & $28(16.8)$ & $243(21.5)$ & $27(25.7)$ & $16(12.4)$ & $26(21.8)$ & $15(17.6)$ & $84(19.2)$ \\
\hline $40-49$ & $68(18.0)$ & 71 (21.9) & 55 (21.0) & $42(25.1)$ & 236 (20.9) & 19 (18.1) & $29(22.5)$ & $17(14.3)$ & $12(14.1)$ & 77 (17.6) \\
\hline $50-59$ & $67(17.8)$ & $54(16.7)$ & $46(17.6)$ & $33(19.8)$ & $200(17.7)$ & $15(14.3)$ & $18(14.0)$ & $17(14.3)$ & $9(10.6)$ & $59(13.5)$ \\
\hline $60-69$ & $46(12.2)$ & 38 (11.7) & $40(15.3)$ & $17(10.2)$ & $141(12.5)$ & 14 (13.3) & 24 (18.6) & $17(14.3)$ & $18(21.2)$ & $73(16.7)$ \\
\hline $70-79$ & $20(5.3)$ & $30(9.3)$ & $16(6.1)$ & $18(10.8)$ & $84(7.4)$ & $14(13.3)$ & $16(12.4)$ & 23 (19.3) & $17(20.0)$ & $70(16.0)$ \\
\hline$\geq 80$ & $4(1.1)$ & $8(2.5)$ & $8(3.1)$ & $7(4.2)$ & $27(2.4)$ & $3(2.9)$ & $12(9.3)$ & $10(8,4)$ & $9(10.6)$ & $34(7.8)$ \\
\hline \multirow[t]{2}{*}{ Total } & 377 & 324 & 262 * & 167 & 1,130 & 105 ** & 129 & 119 & 85 & 438 \\
\hline & $(100.0)$ & $(100.0)$ & (100.0) & (100.0) & (100.0) & $(100.0)$ & $(100.0)$ & $(100.0)$ & $(100.0)$ & (100.0) \\
\hline \multirow{2}{*}{\multicolumn{11}{|c|}{$\begin{array}{l}\text { Median age at } \\
\text { death (years) }\end{array}$}} \\
\hline & & & & & & & & & & \\
\hline Male & 43.5 & 43.5 & 45.0 & 45.5 & 44,5 & 46.5 & 48.5 & 53.5 & 51.5 & 49.0 \\
\hline Female & 37.5 & 46.5 & 45.0 & 51.0 & 43,5 & 49.5 & 56.0 & 58.5 & 65.5 & 57.5 \\
\hline Total & 41.5 & 44.5 & 45.0 & 47.5 & 43.5 & 46.5 & 52.5 & 54.5 & 60.5 & 53.5 \\
\hline \multirow{4}{*}{\multicolumn{11}{|c|}{$\begin{array}{l}\text { Mean number of causes } \\
\text { of death per death } \\
\text { certificate and respective } \\
\text { standard deviation }\end{array}$}} \\
\hline & & & & & & & & & & \\
\hline & & & & & & & & & & \\
\hline & & & & & & & & & & \\
\hline Mean & 2.8 & 3.1 & 3.2 & 3.6 & NC & 3.7 & 4.0 & 4.0 & 4.5 & NC \\
\hline Standard deviation & 1.0 & 1.1 & 1.2 & 1.2 & $\mathrm{NC}$ & 1.0 & 1.1 & 1.3 & 1.2 & $\mathrm{NC}$ \\
\hline
\end{tabular}

Source: SEADE Foundation.

NC: not calculated.

* Excluding 1 death at an unknown age, between 1996 and 2000;

** Excluding 1 death at an unknown age, between 1985 and 1990. 
Deaths from cysticercosis (absolute number and \%) according to main associated causes of death and periods. São Paulo State, Brazil, $1985-2004$.

\begin{tabular}{|c|c|c|c|c|c|c|c|c|}
\hline \multirow[t]{2}{*}{$\begin{array}{l}\text { Associated causes of death (not underlying) } \\
(I C D-9) *(I C D-10) * *\end{array}$} & \multicolumn{2}{|c|}{$\begin{array}{l}1985-1990 \\
\text { (deaths }=377 \text { ) }\end{array}$} & \multicolumn{2}{|c|}{$\begin{array}{l}\text { 1991-1995 } \\
\text { (deaths }=324 \text { ) }\end{array}$} & \multicolumn{2}{|c|}{$\begin{array}{l}1996-2000 * \star \star \\
\text { (deaths }=263)\end{array}$} & \multicolumn{2}{|c|}{$\begin{array}{c}2001-2004 \\
\text { (deaths }=167 \text { ) }\end{array}$} \\
\hline & $\mathbf{n}$ & $\%$ & n & $\%$ & $\mathbf{n}$ & $\%$ & $\mathrm{n}$ & $\%$ \\
\hline Intracranial hypertension (348.2) * (G93.2) ** & 112 & 29.7 & 83 & 25.6 & 54 & 20.5 & 37 & 22.2 \\
\hline Pneumonias $(480-486) *(J 12-J 18)$ ** & 67 & 17.8 & 76 & 23.5 & 60 & 22.8 & 37 & 22.2 \\
\hline Cerebral edema (348.5) * (G93.6) ** & 54 & 14.3 & 37 & 11.4 & 35 & 13.3 & 14 & 8.4 \\
\hline Hydrocephalus (331.4)* (G91) ** & 53 & 14.1 & 53 & 16.4 & 49 & 18.6 & 42 & 25.1 \\
\hline $\begin{array}{l}\text { Inflammatory diseases of the central nervous system } \\
(320-326) *(G 00-G 09) * \star\end{array}$ & 38 & 10.1 & 35 & 10.8 & 27 & 10.3 & 21 & 12.6 \\
\hline Cardiorespiratory arrest $(427.5,799.1) *(146.9$, R092) ** & 35 & 9.3 & 41 & 12.7 & 28 & 10.6 & 19 & 11.4 \\
\hline Other respiratory diseases principally affecting the & & & & & & & & \\
\hline interstitium $(514.0-516.9,518.5)$ * (J80-J84) ** & 26 & 6.9 & 24 & 7.4 & 9 & 3.4 & 10 & 6.0 \\
\hline Cerebrovascular diseases $(430-438)$ * $(160-169)$ ** & 25 & 6.6 & 21 & 6.5 & 26 & 9.9 & 15 & 9.0 \\
\hline Shock, not elsewhere classified (785.5) * (R57) ** & 22 & 5.8 & 17 & 5.2 & 10 & 3.8 & 6 & 3.6 \\
\hline Respiratory failure, not elsewhere classified $(786.0) *(\mathrm{~J} 96)$ ** & 21 & 5.6 & 32 & 9.9 & 44 & 16.7 & 32 & 19.2 \\
\hline $\begin{array}{l}\text { Epilepsy, status epilepticus, and convulsions }(345,780.3) \text { * } \\
(\text { G40-G41, R56.8) ** }\end{array}$ & 17 & 4.5 & 20 & 6.2 & 27 & 10.3 & 19 & 11.4 \\
\hline Coma $(780.0) *(R 40.2) * \star$ & 17 & 4.5 & 16 & 4.9 & 7 & 2.7 & 8 & 4.8 \\
\hline Septicemias $(038) *(A 40-A 41) * *$ & 16 & 4.2 & 22 & 6.8 & 29 & 11.0 & 29 & 17.4 \\
\hline Other disorders of the nervous system & & & & & & & & \\
\hline $\begin{array}{l}(348.0-348.1,348.3-348.4,348.8-348.9) * \\
(G 93.0-G 93.1, \text { G93.3-G93.5, G93.7-G93.9) ** }\end{array}$ & 14 & 3.7 & 9 & 2.8 & 9 & 3.4 & 8 & 4.8 \\
\hline Hypertensive diseases $(401-404) *(110-113)$ ** & 9 & 2.4 & 9 & 2.8 & 8 & 3.0 & 8 & 4.8 \\
\hline $\begin{array}{l}\text { Malnutrition and cachexia }(260-263,799.4) \text { * } \\
(\text { E40-E46. R64) ** }\end{array}$ & 9 & 2.4 & 13 & 4.0 & 9 & 3.4 & 7 & 4.2 \\
\hline Failure of multiple organs $(799.8) *(\mathrm{R} 68.8)$ ** & 9 & 2.4 & 6 & 1.9 & 10 & 3.8 & 12 & 7.2 \\
\hline Diabetes mellitus (250) * (E10-E14) ** & 7 & 1.9 & 6 & 1.9 & 7 & 2.7 & 3 & 1.8 \\
\hline Aspiration pneumonia $(507.0) *(\mathrm{~J} 69.0)$ ** & 7 & 1.9 & 7 & 2.2 & 7 & 2.7 & 5 & 3.0 \\
\hline $\begin{array}{l}\text { Surgical operation and other procedures as the cause of } \\
\text { abnormal reaction (E878-E879)*(Y83-Y84)** }\end{array}$ & 7 & 1.9 & 16 & 4.9 & 14 & 5.3 & 11 & 6.6 \\
\hline Urinary tract infection, site not specified (599.0) * (N39.0) ** & 0 & 0.0 & 5 & 1.5 & 8 & 3.0 & 6 & 3.6 \\
\hline
\end{tabular}

Source: SEADE Foundation.

Note: percents (\%) related to the number of deaths.

* Rubrics and codes of the International Classification of Diseases, ninth revision (ICD-9), 1985-1995 18;

** Rubrics and codes of the International Classification of Diseases, tenth revision (ICD-10), 1996-2004 19;

*** Data for the year 1996 are partial.

Underlying causes of death with cysticercosis as an associated cause

Table 3 shows the underlying causes of death when cysticercosis was identified as an associated cause. HIV/AIDS was the principal underlying cause for the entire period (1985-2004), increasing from $11.3 \%$ in $1985-1990$ to $21.2 \%$ in 2001-2004. Next came cerebrovascular diseases, frequently occurring together with cysticercosis as either an associated cause (as above) or the underlying cause. Median age at death for all these cases was 53.5 years, but varying between the underlying causes: 35.5 years for deaths due to AIDS, 56.0 years for neoplasms, 58.5 years for ischemic heart disease, 62.5 years for cerebrovascular diseases, and 63.5 for other diseases of the circulatory system.

\section{Number of causes mentioned per death certificate}

The mean number of causes mentioned on death certificates increased over the four sub-periods. The figures were always lower for cysticercosis as the underlying cause, i.e., 2.84 ( \pm 0.98$), 3.06$ 
Underlying causes of death (absolute number and \%) when cysticercosis was listed as an associated cause, according to time periods. São Paulo State, Brazil, 1985-2004.

\begin{tabular}{|c|c|c|c|c|c|c|c|c|}
\hline \multirow[t]{2}{*}{ Underlying causes of death (ICD-9)* (ICD-10)** } & \multicolumn{2}{|c|}{$1985-1990$} & \multicolumn{2}{|c|}{$1991-1995$} & \multicolumn{2}{|c|}{$1996-2000 * \star \star$} & \multicolumn{2}{|c|}{ 2001-2004 } \\
\hline & n & $\%$ & $\mathrm{n}$ & $\%$ & $\mathrm{n}$ & $\%$ & $\mathrm{n}$ & $\%$ \\
\hline Human immunodeficiency virus (HIV) disease (AIDS) (279.1)* (B20-B24) ** & 12 & 11.3 & 27 & 20.9 & 20 & 16.8 & 18 & 21.2 \\
\hline Malignant neoplasms $(140-208) *(C 00-C 97) * *$ & 9 & 8.5 & 13 & 10.1 & 12 & 10.1 & 12 & 14.1 \\
\hline Ischemic heart diseases $(410-414) *(120-125) * *$ & 9 & 8.5 & 18 & 14.0 & 12 & 10.1 & 6 & 7.1 \\
\hline Cerebrovascular diseases $(430-438) *(160-169)$ ** & 18 & 17.0 & 22 & 17.1 & 22 & 18.5 & 12 & 14.1 \\
\hline $\begin{array}{l}\text { Other diseases of the circulatory system }(390-405,415-429,440-459) \text { * } \\
(100-113,126-151,170-199) \text { ** }\end{array}$ & 12 & 11.3 & 14 & 10.9 & 19 & 16.0 & 10 & 11.8 \\
\hline Remaining underlying causes of death & 46 & 43.4 & 35 & 27.1 & 34 & 28.6 & 27 & 31.8 \\
\hline Total & 106 & 100.0 & 129 & 100.0 & 119 & 100.0 & 85 & 100.0 \\
\hline
\end{tabular}

Source: SEADE Foundation.

* Rubrics and codes of the International Classification of Diseases, ninth revision (ICD-9), 1985-1995 18;

** Rubrics and codes of the International Classification of Diseases, tenth revision (ICD-10), 1996-2004 19;

$\star \star \star$ Data for the year 1996 are partial.

$( \pm 1.06), 3.24( \pm 1.21)$, and $3.59( \pm 1.22)$, respectively, as compared to cysticercosis as an associated cause, namely $3.69( \pm 1.00), 4.03$ ( \pm 1.08$)$, $4.02( \pm 1.26)$, and $4.54( \pm 1.24)$ (Table 1).

\section{Place of residence}

Table 4 shows the 25 counties with at least 10 cysticercosis-related deaths each from 1985 to 2004, accounting for $42.2 \%$ of all such deaths in the State of São Paulo during the 20-year period. Cysticercosis-related death was particularly frequent in the counties of São Paulo, Campinas, Ribeirão Preto, Santo André, and Guarulhos. The table lists the counties in decreasing order according to the proportion in which cysticercosis was identified as underlying cause of death, in relation to the total number of times it was stated on the death certificates. This indicator varies noticeably, from 92.9\% in Araraquara to as low as $51.2 \%$ in Ribeirão Preto. Some $2.9 \%(40 / 1,570)$ of the deaths in the State of São Paulo were individuals who lived in other States of Brazil, and they were included in this study because the number was small.

\section{Place of death}

Most cysticercosis-related deaths occurred in hospitals or other health care facilities, either as the underlying cause or as an associated cause ( $88.5 \%$ and $84.3 \%$, respectively), as compared to the home (10.3\% and $13 \%$, respectively).

\section{Discussion}

Mortality statistics suffer from two types of limitations, quantitative and qualitative. In the State of São Paulo, quantitative limitations in the coverage of the actual number of deaths are negligible. The relationship between deaths reported to SEADE Foundation and those estimated by available demographic projections for recent years shows figures close to $100 \%$, suggesting good coverage in the mortality data. With regard to qualitative limitations in the State, ill-defined causes were listed as the underlying cause of death in only $5.98 \%, 6.25 \%, 6.39 \%$, and $6.5 \%$, respectively, among the total number of deaths in each of the four sub-periods. These percentages are less than half the national figures for Brazil. Furthermore, no difficulties were encountered in transforming causes of death into ICD codes, among the death certificates mentioning cysticercosis. The coding work was accurate and did not constitute a source of error that might have compromised the quality of the mortality data 21 .

The title of this work was originally intended to indicate a study on neurocysticercosis-related mortality. However, subcategory 123.1 of ICD-9 18 included all forms of cysticercosis, thus making it impossible to identify isolated CNS cysticercus infection. In ICD-9, valid from 1979 to 1995 , there was not even any provision for the term "neurocysticercosis" in the index (volume 2) for designating CNS cysticercosis 22. This gap was corrected in ICD-10 19, with category B69 including four subcategories: cysticercosis involving 
Table 4

Cysticercosis-related deaths, total listings, underlying cause of death, and percentage of underlying causes in relation to total listings, according to municipalities with the most deaths. São Paulo State, Brazil, 1985-2004.

\begin{tabular}{|c|c|c|c|}
\hline Municipalities * & $\begin{array}{c}\text { Total listings } \\
\text { (1) }\end{array}$ & $\begin{array}{c}\text { Underlying } \\
\text { cause (2) }\end{array}$ & $\begin{array}{c}\% \\
(2 / 1)\end{array}$ \\
\hline Araraquara & 14 & 13 & 92.9 \\
\hline Itaquaquecetuba & 10 & 9 & 90.0 \\
\hline Marília & 18 & 16 & 88.9 \\
\hline Diadema & 13 & 11 & 84.6 \\
\hline Franca & 13 & 11 & 84.6 \\
\hline São José do Rio Preto & 24 & 20 & 83.3 \\
\hline Catanduva & 12 & 10 & 83.3 \\
\hline São Bernardo do Campo & 16 & 13 & 81.3 \\
\hline Campinas & 46 & 37 & 80.4 \\
\hline Botucatu & 16 & 12 & 75.0 \\
\hline Assis & 12 & 9 & 75.0 \\
\hline Sorocaba & 21 & 15 & 71.4 \\
\hline Barueri & 10 & 7 & 70.0 \\
\hline São Caetano do Sul & 10 & 7 & 70.0 \\
\hline São José dos Campos & 10 & 7 & 70.0 \\
\hline Osasco & 24 & 16 & 66.7 \\
\hline Mauá & 12 & 8 & 66.7 \\
\hline Jundiaí & 20 & 13 & 65.0 \\
\hline Santo André & 33 & 21 & 63.6 \\
\hline Limeira & 11 & 7 & 63.6 \\
\hline São Paulo & 226 & 141 & 62.4 \\
\hline Guarulhos & 26 & 16 & 61.5 \\
\hline Mogi-Guaçu & 10 & 6 & 60.0 \\
\hline Rio Claro & 12 & 7 & 58.3 \\
\hline Ribeirão Preto & 43 & 22 & 51.2 \\
\hline
\end{tabular}

Source: SEADE Foundation.

* A complete list of municipalities with cysticercosis-related deaths can be obtained from the author. in the current study by reviewing the records in which cysticercosis had been identified as an associated cause. This was done because of lack of updating in the decision tables for automatic processing of causes of death. The revision was possible because the records in the mortality database were transcribed from data on the death certificates. Causes of death are reproduced in the records by means of ICD codes, according to the line and position on the line in which they were stated in the death certificate. Some 192 records were modified; when these were added to the 939 identified in the databases, the result was a total of 1,131 deaths in which cysticercosis was considered the underlying cause of death.

The importance of the current study is that for the first time it presents the trend and distribution of cysticercosis-related mortality for the State of São Paulo over a 20-year period (19852004), describing the causes of death using both underlying cause and multiple causes. There was a marked decline in the standardized mortality rate for cysticercosis as the underlying cause, especially among adult males. However, for deaths in which cysticercosis was an associated cause, the standardized rates (which were lower than those for the underlying cause) did not show the same downward trend.

The declining cysticercosis mortality rates may be due to decreased incidence or a reduction in case-fatality. Cysticercosis prevalence is unknown, because reporting the disease is not officially mandatory. Moreover, various authors agree that there is a lack of knowledge on the factors accounting for the high endemicity of cysticercosis in some regions of the State $4,5,7$. It is reasonable to posit that nonspecific sanitation measures and improved schooling and socioeconomic conditions may have caused this drop in incidence. Meanwhile, the reduction in case-fatality would likely be related to more effective health care, including early diagnosis, medication, and (neuro)surgical treatment 3,5 , as reflected in the increasing median age at death observed in this study.

The use of a multiple-cause methodology allows retrieving not only the underlying cause of death but also other associated causes listed on the death certificate. Knowledge of the associated causes opens new prospects for preventing deaths. The fact that intracranial hypertension, hydrocephalus, cerebral edema, and inflammatory diseases of the CNS were the principal associated causes is consistent with a study on cysticercosis-related mortality in California 8 and with clinical case reports and autopsy reports in Brazil 3,4,6,7. Associated causes classified as terminal, such as pneumonia, septicemia, shock, 
and coma, reflect the severity of the cysticercosis disease process leading to death.

The retrieval of deaths in which cysticercosis was identified as an associated cause is another advantage of the multiple-cause methodology. By considering all listing of cysticercosis on death certificates, the consolidated mortality rate for the State over the 20-year period increased by nearly $40 \%$. By considering all listing of cysticercosis, the underlying causes of these deaths were identified. This study confirmed the expected increase in the frequency of co-infection involving the AIDS epidemic in endemic cysticercosis areas 23,24,25. AIDS was increasingly present in cysticercosis-related mortality. The relationship between AIDS and cysticercosis thus merits further study. The question is whether the association between AIDS and cysticercosis is exceptional or random ${ }^{4}$, or whether AIDS-related immune impairment aggravates the effects of cysticercosis.

The association between cysticercosis and cerebrovascular diseases requires additional comment. In this study, cerebrovascular diseases were an associated cause in $7.69 \%(87 / 1,131)$ of deaths with cysticercosis as the underlying cause, and were identified as the underlying cause in $16.86 \%$ of deaths $(74 / 439)$ in which cysticercosis was an associated cause. The international literature advises detailed examination and caution in accepting a causal relationship between neurocysticercosis and cerebrovascular disease 26 . This is reflected in the decision tables for automatic processing, in which this causal relationship, which had not existed previously 16 , was only recently included 17 . In the present work, the causes of death in the records in which this association was mentioned were not modified. Acceptance of this causal relationship would cause partial redefinition of the causes of death among the 74 deaths in which cerebrovascular diseases were the underlying cause of death.

This study showed a progressive decline in cysticercosis as the underlying cause of death over the 20-year period. In these deaths, cysticercosis became an associated cause that was not presented in the traditional mortality statistics. Mortality information is used to back health care policy planning and funding initiatives at the national, state, and local levels 27. Conventionally, the underlying causes of death provide the basis for the mortality statistics. Thus, policy decisions may be made on the basis of data that underestimate some causes of death, including cysticercosis, as demonstrated here. This parasitic disease has been neglected by public health initiatives 7 , and no specific interventions have been implemented to curtail it 5 .
Estimation of cysticercosis also hinges on the value ascribed to it as the underlying cause by the various medical professionals who have the responsibility for filling out death certificates. The value ascribed to cysticercosis is influenced by various factors, including physician training and specialty, availability of the means to diagnose it, and knowledge of the medical and legal importance of death certificates and the guidelines for properly completing and processing them 10,28 . Differences in the value ascribed to cysticercosis were observed between counties in the State of São Paulo. Assuming that there are no differences in epidemiological characteristics between these municipalities, the variation from 92.9\% in Araraquara to $51.2 \%$ in Ribeirão Preto in identifying cysticercosis as the underlying cause (as compared to all the times it is listed on the death certificate) must be attributed to different interpretations of its relevance to the death. Such differences primarily reflect variations in certifying the death, rather than epidemiological differences in cysticercosis between counties 10. Less value was ascribed in some counties with more deaths, such as Ribeirão Preto, Guarulhos, São Paulo, Santo André, and Jundiaí, in which the low percentages tend to weigh in the overall figure of $72.04 \%(1,131 / 1,570)$ of cysticercosis as underlying cause, out of the total number of deaths involving cysticercosis during the study period.

\section{Conclusions}

This study discussed the magnitude of cysticercosis-related mortality with the disease classified as the underlying cause of death versus as an associated cause, using a multiple-cause-of-death methodology. Despite the tendency to disregard and underestimate cysticercosis as the underlying cause in some municipalities, the study showed a decreasing trend in the corresponding rate for the State of São Paulo. Meanwhile, as an associated cause of death, the methodology complemented and surmounted the limitations of the underlying-cause approach and highlighted some aspects of cysticercosis pathogenesis that merit further attention, especially its association with AIDS and cerebrovascular diseases. The multiple-cause methodology identified these facts and opened prospects for research to improve cysticercosis-related mortality data and clarify doubts about its natural history. The use of multiple causes of death in conjunction with the traditional underlying-causes method is therefore recommended for planning health policies related to cysticercosis. 


\section{Resumo}

A mortalidade relacionada à cisticercose na população não tem sido pesquisada no Brasil. Foram estudados os óbitos registrados entre 1985 e 2004 no Estado de São Paulo em que a cisticercose foi mencionada em qualquer linha ou parte da Declaração de Óbito. As causas de morte foram processadas pelo Tabulador de Causas Múltiplas. No período de vinte anos ocorreram 1.570 óbitos, sendo a cisticercose causa básica em 1.131 e causa associada de morte em 439. Os coeficientes padronizados de mortalidade por cisticercose como causa básica apresentaram tendência de declínio, foram maiores entre os homens e nas idades mais avançadas. As principais causas associadas nas mortes por cisticercose foram hipertensão intracraniana, ede- ma cerebral, hidrocefalias, doenças inflamatórias do sistema nervoso central e doenças cerebrovasculares. A AIDS foi a principal causa básica nas mortes com a cisticercose como causa associada. Os municípios com maior número de mortes foram São Paulo, Campinas, Ribeirão Preto e Santo André. Observou-se grande variação entre os municípios na valorização da cisticercose como causa básica de morte, determinando sua subestima para subsidiar o planejamento de políticas de saúde.

Cisticercose; Causas Múltiplas de Morte; Coeficiente de Mortalidade

\section{References}

1. World Health Organization. Neurological disorders: public health challenges. Geneva: World Health Organization; 2006.

2. World Health Organization. Control of neurocysticercosis: report by the Secretariat. In: 56th World Health Assembly. http://www.who.int/gb/ebwha/ pdf_files/WHA56/ea5610.pdf (accessed on 22/ Feb/2007).

3. Colli BO, Martelli N, Assirati Junior JA, Machado HR, Salvarani CP, Sassoli VP, et al. Cysticercosis of the central nervous system. I. Surgical treatment of cerebral cysticercosis: a 23 years experience in the Hospital das Clínicas of Ribeirão Preto Medical School. Arq Neuropsiquiatr 1994; 52:166-86.

4. Chimelli L, Lovalho AF, Takayanagui OM. Neurocisticercose: contribuição da necropsia na consolidação da notificação compulsória em Ribeirão Preto-SP. Arq Neuropsiquiatr 1998; 56:577-84.

5. Takayanagui OM, Leite JP. Neurocisticercose. Rev Soc Bras Med Trop 2001; 34:283-90.

6. Lino Jr. RS, Reis MA, Teixeira VPA. Ocorrência de cisticercose (Cysticercus cellulosae) encefálica e cardíaca em necropsias. Rev Saúde Publica 1999; 33:495-98.

7. Agapejev S. Aspectos clínico-epidemiológicos da neurocisticercose no Brasil. Arq Neuropsiquiatr 2003; 61:822-8.
8. Sorvillo FJ, Portigal L, DeGiorgio C, Smith L, Waterman SH, Berlin GW, et al. Cysticercosis-related deaths, California. Emerg Infect Dis 2004; 10:465-9.

9. Oeberst JL, Barnard EH, Bigio EH, Prahlow JA. Neurocysticercosis. Am J Forensic Med Pathol 2002; 23:31-5.

10. Santo AH. Causas múltiplas de morte: formas de apresentação e métodos de análise [Doctoral Dissertation]. São Paulo: Faculdade de Saúde Pública, Universidade de São Paulo; 1988.

11. Brasil. Lei $n^{\circ}$. 6.015, de 31 de dezembro de 1973. Dispõe sobre os registros públicos, e dá outras providências. Diário Oficial da União 1973; 31 dez.

12. Ministério da Saúde. Sistema de informações sobre mortalidade: manual de procedimentos. Brasília: Ministério da Saúde; 1999.

13. Organização Mundial da Saúde. Classificação estatística internacional de doenças e problemas relacionados à saúde: $10^{\text {a }}$ revisão. v. 2: manual de instrução. São Paulo: Centro Colaborador da OMS para a Classificação de Doenças em Português/ Edusp;1993.

14. Pinheiro CE, Santo AH. Processamento de causas de morte em lote pelo sistema de seleção de causa básica. Rev Saúde Pública 1998; 32:72-3. 
15. Santo AH, Pinheiro CE. Uso do microcomputador na seleção da causa básica de morte. Bol Oficina Sanit Panam 1995; 119:319-27.

16. National Center for Health Statistics. Instruction manual 2c: ICD-9 ACME decision tables for classifying the underlying causes of death, 1992. Hyattsville: National Center for Health Statistics; 1992.

17. National Center for Health Statistics. Instruction manual 2c: ICD-10 ACME decision tables for classifying the underlying causes of death, 2006. Hyattsville: National Center for Health Statistics; 2005.

18. Organização Mundial da Saúde. Manual da classificação estatística internacional de doenças, lesões e causas de óbito: 9a revisão. v. 1. São Paulo: Centro Colaborador da OMS para a Classificação de Doenças em Português; 1985.

19. Organização Mundial da Saúde. Classificação estatística internacional de doenças e problemas relacionados à saúde: 10ạ revisão. v. 1. São Paulo: Centro Colaborador da OMS para a Classificação de Doenças em Português/Edusp; 1993.

20. Santo AH, Pinheiro CE. Tabulador de causas múltiplas de morte. Rev Bras Epidemiol 1999; 2:90-7.

21. Santo AH. Avaliação da qualidade da codificação das causas de morte no Estado de São Paulo, Brasil. Inf Epidemiol SUS 2000; 9:189-98.
22. Organização Mundial da Saúde. Manual da classificação estatística internacional de doenças, lesões e causas de óbito: 9a revisão. v. 1: índice alfabético. São Paulo: Centro Colaborador da OMS para a Classificação de Doenças em Português; 1980.

23. Thornton CA, Houston S, Latif AS. Neurocysticercosis and human immunodeficiency virus infection. A possible association. Arch Neurol 1992; 49:963-5.

24. Soto Hernandez JL, Ostrosky Zeichner L, Tavera G, Gomez Avina A. Neurocysticercosis and HIV infection: report of two cases and review. Surg Neurol 1996; 45:57-61.

25. Delobel P, Signate A, El Guedj M, Couppie P, Smadja D, Pradinaud R. Unusual form of neurocysticercosis associated with HIV infection. Eur J Neurol 2004; 11:55-8.

26. Rocha MSG, Brucki SMD, Ferraz AC, Piccolo AC. Doença cerebrovascular e neurocisticercose. Arq Neuropsiquiatr 2001; 59:778-83.

27. Redelings MD, Sorvillo F, Simon P. A comparison of underlying cause and multiple causes of death. Epidemiology 2006; 17:100-3.

28. Wall MM, Huang J, Oswald J, McCullen D. Factors associated with reporting multiple causes of death. BMC Med Res Methodol 2005; 5:4.

Submitted on 08/Mar/2006

Final version resubmitted on 07/Mar/2007

Approved on 30/Mar/2007 